\title{
Analysis of International Competitiveness of Chinese Textile and Clothing
}

\author{
Jian WU and An LU* \\ Beijing Institute of Fashion Technology, Beijing China \\ wujian189@outlook.com, sxylan@bift.edu.cn \\ ${ }^{*}$ Corresponding author
}

Keywords: international competitiveness, textile, clothing

Abstract. In this paper, the international market share, trade competitiveness index and revealed comparative advantage index are adopted to analyze the international competitiveness of China's textile and apparel industry, and SWOT analysis is used to analyze the domestic textile and apparel industry. The research results show that the international competitiveness of China's textiles and clothing is gradually decreasing, but still has a strong international competitiveness, China's textile and clothing industry is facing threats.

\section{Introduction}

China is one of the world textile clothing production and the exportation countries, the production and the export volume ranks the world front row. After China's entry into WTO, China's textile and garment export trade has developed steadily. With the cancellation of quota in January 2005, the development of world textile and garment trade entered a new stage. China's textile and garment export trade was repeatedly restricted by the us and Europe, which led to strong fluctuations in export policies and competition from more developing countries [1]. India, Turkey, Pakistan, Indonesia, Vietnam, Mexico and other countries, these countries have a strong textile clothing production capacity, enjoy better than China's trade policies, directly affect China's textile clothing international market share. Relevant studies show that China's labor-intensive textile and clothing exports depend on the comparative advantage of natural resources and labor resources, which is also the comparative advantage of other developing countries in textile and clothing [2]. In addition, China has not formed its own international brand, has been only able to produce low value-added products, unable to form a brand advantage as soon as possible. Products with low technical content, lack of design innovation ability, low product standards, suffered from other countries with higher technical content of the same product competition and loss of competitiveness. Therefore, the international competitiveness of China's textile clothing has become one of the focus of textile clothing export enterprises [3].

\section{Country Profiles}

China is located in the east of Eurasia and the west coast of the Pacific Ocean. It is also a country with a large population. According to the sixth census, China's total population now exceeds 1.3 billion. By 2016, China's GDP reached 11.19 trillion us dollars, ranking second in the world. GDP per capita reached us $\$ 8,117$, ranking 78 th in the world. China is a developing country with large GDP and insufficient per capita.

\section{Current Situation of China's Textile and Garment Trade}

From 2008 to 2014, China's textile and garment exports have been on the rise. As shown in Fig.1, the export of textiles and clothing reached the maximum value of $\$ 111.722$ billion and $\$ 186.703$ billion respectively in 2014. Since 2014, both textile and clothing exports have been declining. Moreover, the proportion of textiles and clothing in the total exports of goods has been declining. As shown in Table 1, the textile exports dropped from 4.57\% in 2008 to 3.12\% in 2016.Clothing exports dropped from 8.42 percent in 2008 to 5.74 percent in 2016. Although the export volume of the textile and clothing industry continues to decrease, the export volume of the textile and clothing industry in 
2016 still accounts for $8.86 \%$ of the total national export volume, which is still a large proportion and has a great impact on the national economy.

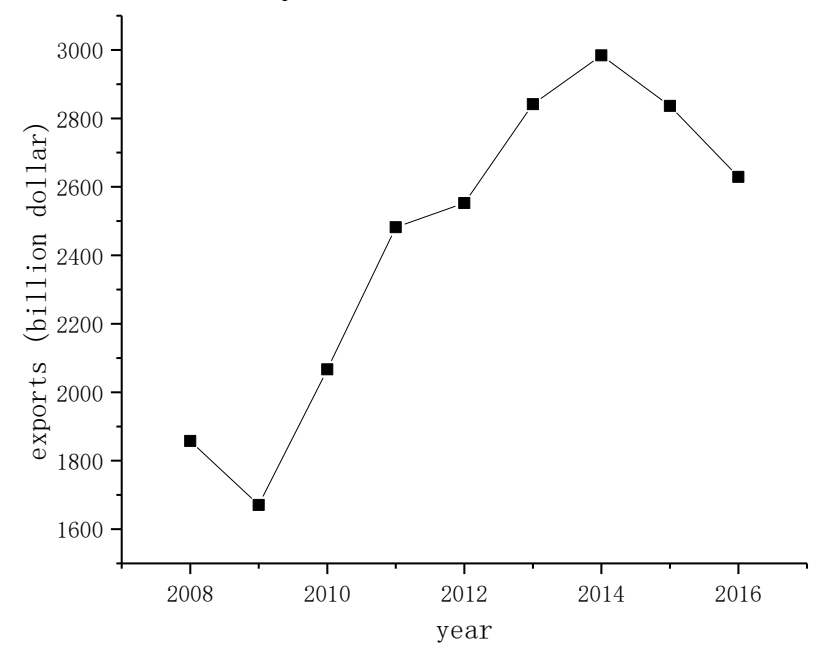

Fig 1 China's textile and garment exports from 2008 to 2016.

Table 1 The proportion of textile and apparel exports in China's total exports from 2008 to 2016.

\begin{tabular}{ccc}
\hline year & $\begin{array}{c}\text { The proportion of } \\
\text { textile exports }\end{array}$ & Clothing exports accounted for \\
\hline 2008 & $4.57 \%$ & $8.42 \%$ \\
2009 & $5.44 \%$ & $10.02 \%$ \\
2010 & $4.14 \%$ & $7.63 \%$ \\
2011 & $3.44 \%$ & $6.34 \%$ \\
2012 & $3.19 \%$ & $5.88 \%$ \\
2013 & $2.96 \%$ & $5.45 \%$ \\
2014 & $2.79 \%$ & $5.14 \%$ \\
2015 & $2.88 \%$ & $5.30 \%$ \\
2016 & $3.12 \%$ & $5.74 \%$ \\
\hline
\end{tabular}

\section{Analysis on the International Competitiveness of China's Textile and Garment Industry}

There are multiple ways to analyze the international competitiveness of a country's product. Here, three indicators are adopted to measure the international competitiveness of domestic textiles and apparel, namely, international market share (MS), trade competitiveness index (TC) and revealed comparative advantage index (RCA).

\subsection{International market share}

International market share is the proportion of a country's export of a certain product in the total export of the same kind of products in the world. It is the most direct reflection of the strength of competitiveness. The higher the international market share, the stronger the international competitiveness, and vice versa. Its calculation formula is as follows:

$$
\mathrm{MS}_{\mathrm{ij}}=\mathrm{X}_{\mathrm{ij}} / \mathrm{X}_{\mathrm{wj}}
$$

Where, $M S_{i j}$ represents the international market share, $X_{i j}$ represents the export volume of product $j$ in country $i$, and $X_{w j}$ represents the total export volume of product $j$ in the world.

From the data in Table 2, it can be seen that from 2008 to 2016, the international market share of China's textiles fluctuated between $26 \%$ and $37 \%$, and that of clothing fluctuated between $33 \%$ and $39 \%$. The international market share of textiles grew slowly from 2012 to 2016. The international market share of clothing peaked at 39\% in 2015 and dropped to $36 \%$ in 2016. 
Table 2 International market share of domestic textile clothing from 2008 to 2016.

\begin{tabular}{lcc}
\hline year & textile & clothing \\
\hline 2008 & $26 \%$ & $33 \%$ \\
2009 & $28 \%$ & $34 \%$ \\
2010 & $30 \%$ & $37 \%$ \\
2011 & $32 \%$ & $37 \%$ \\
2012 & $34 \%$ & $38 \%$ \\
2013 & $35 \%$ & $39 \%$ \\
2014 & $36 \%$ & $39 \%$ \\
2015 & $37 \%$ & $39 \%$ \\
2016 & $37 \%$ & $36 \%$ \\
\hline
\end{tabular}

\subsection{Trade competitiveness index}

TC index mainly refers to the ratio of the net export volume of a certain product to the total import and export volume of a country or region. The advantage of this index is that it excludes the impact of macro aggregate fluctuations such as inflation and exchange rate fluctuations, and is a relative value of the total trade volume. TC index is used to measure whether the same products produced by a country are at a competitive advantage or disadvantage and the degree of advantage and disadvantage. Its calculation formula is as follows:

$$
\mathrm{TC}_{\mathrm{ij}}=\left(\mathrm{X}_{\mathrm{ij}}-\mathrm{M}_{\mathrm{ij}}\right) /\left(\mathrm{X}_{\mathrm{ij}}+\mathrm{M}_{\mathrm{ij}}\right)
$$

Where, $T C_{i j}$ represents the trade competitiveness index of $j$ products in country $i, X_{i j}$ represents the export volume of $j$ products in country $i$, and $M_{i j}$ represents the import volume of $j$ products in country $i$.

From 2008 to 2016, as shown in the table 4, China's textile trade competitiveness index was between 0.6 and 0.73 , with an obvious competitive advantage. In the same period, the trade competitiveness index of clothing was between 0.92 and 0.97 , with a very obvious competitive advantage. The value of $T C_{i j}$ is $(-1,1)$, and the relationship between TC value and competitiveness is shown in Table 3:

Table 3 Relation between TC value and international competitiveness of products.

\begin{tabular}{ll}
\hline TC value & International competitiveness \\
\hline$(-1,-0.8]$ & Very clear competitive disadvantage \\
$(-0.8,-0.5]$ & Obvious competitive disadvantage \\
$(-0.5,0)$ & Have a competitive disadvantage \\
Close to 0 & Equal to the international average competitiveness \\
$(0,0.5)$ & Have a competitive advantage \\
{$[0.5,0.8)$} & Clear competitive advantage \\
{$[0.8,1)$} & Very clear competitive advantage \\
\hline
\end{tabular}

Table 4. China's textile and apparel trade competitiveness TC index from 2008 to 2016.

\begin{tabular}{ccc}
\hline year & textile & clothing \\
\hline 2008 & 0.601038888 & 0.962791625 \\
2009 & 0.600239939 & 0.966227687 \\
2010 & 0.62604719 & 0.961940624 \\
2011 & 0.666396127 & 0.94914163 \\
2012 & 0.656401672 & 0.944905284 \\
2013 & 0.663563616 & 0.941609129 \\
2014 & 0.69313295 & 0.936028057 \\
2015 & 0.703503659 & 0.927442807 \\
2016 & 0.725134022 & 0.921697775 \\
\hline
\end{tabular}




\subsection{Index of revealed comparative advantage}

RCA is an index first used by American economist Balasa in 1965 to measure the comparative advantage of some countries in trade. Later, it was widely adopted by international organizations such as the world bank. The index is the ratio between a country's share of the total value of its exports of a certain commodity and the share of the total value of the world's exports of that commodity. The calculation formula is as follows:

$$
\mathrm{RCA}_{\mathrm{ij}}=\left(\mathrm{X}_{\mathrm{ij}} / \mathrm{X}_{\mathrm{it}}\right) /\left(\mathrm{X}_{\mathrm{wj}} / \mathrm{X}_{\mathrm{wt}}\right)
$$

Where $R C A_{i j}$ represents the revealed comparative advantage index of product $j$ in country $i, X_{i j}$ represents the export volume of product $j$ in country $i, X_{i t}$ represents the total export volume of all products in country $i, X_{w j}$ represents the export volume of product $j$ in the world, and $X_{w t}$ represents the total export volume of all products in the world.

From 2009 to 2016, China's textiles and clothing have a strong international competitive advantage. The RCA value of textiles is between 2.81 and 3.01, and the RCA value of clothing is between 2.72 and 3.56. From the change of value, the RCA value of textiles decreased slightly, while the RCA value of clothing decreased from 3.54 in 2009 to 2.73 in 2016. The overall RCA index of apparel has been declining year by year, mainly due to the intensified trade competition with textile and apparel exporting countries of other developing countries after the elimination of quota, and China's government has taken measures such as imposing export duties on some products, implementing quotas and export licenses. In general, the display comparative advantage of China's textile clothing is gradually decreasing, and there is a trend of declining international competitiveness. The relationship between RCA value size and competitiveness is shown in table 5 .

Table 5 Relationship between RCA value and international competitiveness of products.

\begin{tabular}{ll}
\hline RCA value & International competitiveness \\
\hline$(0,0.8)$ & No competitive advantage \\
$(0.8,1.25)$ & More average competitive advantage \\
$(1.25,2.5)$ & Strong competitive advantage \\
More than 2.5 & Has a strong competitive advantage \\
\hline
\end{tabular}

Table 6 China textile and apparel index of revealed comparative advantage (RCA) from 2009 to 2016

\begin{tabular}{lll}
\hline year & textile & clothing \\
\hline 2009 & 2.972649649 & 3.543879382 \\
2010 & 2.957671435 & 3.567970476 \\
2011 & 3.092002175 & 3.566258024 \\
2012 & 3.040336358 & 3.437795276 \\
2013 & 3.008934487 & 3.314336814 \\
2014 & 2.880927819 & 3.128857825 \\
2015 & 2.720298205 & 2.852376162 \\
2016 & 2.813525393 & 2.725372403 \\
\hline
\end{tabular}

\section{SWOT Analysis}

In order to more accurately analyze the international competitiveness of the textile and clothing industry, SWOT analysis is adopted to analyze the textile and clothing respectively. Textile industry as an important part of the national economy, its inherent advantages are mainly reflected in large capacity, and stable output. In addition, China's textile industry has abundant labor force. Many enterprises in the industry have adopted automatic production equipment, and the quality of textile fabrics has been improved a lot compared with the hand-woven fabrics in the past. But many of the high-quality raw materials of textiles are imported from overseas. For example, our country imports a large amount of cotton from the United States every year. 
From the perspective of external factors, opportunities for textiles mainly come from the policy level. China's One Belt And One Road policy can expand the market along the route, increase the export volume of China's textiles, and improve the international competitiveness of China's textiles. The made in China 2025 policy is conducive to textile and garment enterprises to upgrade their equipment, further improve the technology and technological content of textile fabrics, and promote the development of textile industry towards high added value. However, the rise of the textile industry in southeast Asian countries is very fast, and its export volume is increasing year by year.

Compared with the textile industry, the garment industry has greater development potential. From the perspective of internal factors, the advantages of domestic garment industry lie in huge production capacity, stable output and sufficient labor force. But behind this huge capacity is a lot of processing. Domestic also has many brands, but the competition is intense, the number of well-known brands is relatively few compared with European and American countries.[4]

From the perspective of internal factors, clothing, like textiles, can expand its overseas market under the Belt And Road policy. China's Internet giants launched the Internet revolution. The clothing industry is also involved. No matter from the production of clothing to the ultimate consumer purchase, every link of the Internet can be involved. This change could unlock the potential of the domestic clothing industry, increasing its added value and profit margins. Similarly, the clothing industry is under threat from southeast Asia. The main reason is the rising labor costs at home, and many garment industries have moved to southeast Asian countries.

\section{Conclusion}

Based on the above analysis, it can be seen that China's textile clothing occupies a large share in the international market and its international competitiveness is very strong. However, it can be seen from the values of MS, TC and RCA of textiles that the potential of China's garment industry is smaller than that of textiles. From the perspective of indicators, TC and RCA values of clothing industry decrease faster than those of textiles, and the trend of decline is obvious. From the perspective of market resource allocation, enterprises are more willing to locate their factories in southeast Asian countries, because the domestic demographic dividend is gradually disappearing.

In order to improve the international competitiveness of China's textile clothing, here are some Suggestions:

\subsection{Intensify design and research.}

The grade and variety structure of China's textile and garment products are still in the middle and low level in the world, with low added value. Should make full use of the comparative advantages in aspects of labor, raw materials, and land, improve the technology content, improve the grade of product quality, improve the ability of product design, the processing technology based on constant innovation, production technology and processing equipment, variable quantity for quality, improve the added value of export textile clothing, gradually developed to the direction of high-end consumer groups, improve the international competitiveness.

\subsection{Implement brand strategy}

We should adopt brand strategy, actively develop our own featured products, cultivate a batch of internationally famous brands in the field of textile and clothing through establishing brand and brand, and strive to occupy the international market with international brands. Not satisfied with stick brand production, take from stick brand development to create independent brand road.

\subsection{Accelerate material structure adjustment}

To change the backward development of textile and garment raw materials and the insufficient supply of imported fabrics and raw materials, improve the localization of fabrics, develop new varieties of textile and garment fabrics, and realize the diversification of raw materials. We will actively develop and utilize wool, flax, cashmere and other high-quality raw materials unique to China, and adhere to the common development of natural and chemical fibers. 


\subsection{Strengthen national policy support}

The policy system of textile and garment export should be improved, and policy-based financial support should be strengthened. Enterprises with strong export ability, good economic benefits and obvious driving effect should be supported, and their technological research and development and technological transformation should be subsidized. We should accelerate the reform of the circulation system of raw materials, establish a standardized market, avoid disorderly competition, and control the price and supply of raw materials such as cotton, wool and chemical fiber so as to ensure the export needs of textiles and garments. We will adjust policies on export tax rebates, export quotas and export licenses to expand the export of textiles and clothing.

\subsection{Give play to the advantages of industrial clusters}

Change the present enterprise scattered, small size, design and development capability and technology innovation ability is weak, the situation of poor profit, giving play to the role of internal textile clothing industry association and take advantage of industry cluster, improve the enterprise scale, reduce production cost, as far as possible to play the spillover effect of innovation, to promote the common development of enterprises in the cluster.

\section{Acknowledgment}

This research was financially supported by: Research and Innovation Project of Beijing Institute of Fashion Technology (120301990122/007).

\section{References}

[1] Chang Yaping. Analysis and development strategy of China's textile industry. Beijing: China textile press, 2005.

[2] Gao Weikai. Analysis of China's textile and garment export competition situation in the postquota period. Journal of international business-university of international business and economics, 2006.

[3] Zheng Liming, Zhang Yanlin. Major challenges faced by China's textile industry in the post-quota era. Enterprise economics, 2005.

[4] Zhang Hongzhi. Research on international competitiveness of China's textile and clothing industry. Statistical research, 2005. 